\title{
Role and Regulation of Wnt/ $\beta$-Catenin in Hepatic Perivenous Zonation and Physiological Homeostasis
}

\author{
Chhavi Goel, ${ }^{*}$ Satdarshan P. Monga, ${ }^{* \dagger}$ and Kari Nejak-Bowen* ${ }^{\star \ddagger}$
}

From the Departments of Pathology* and Medicine, ${ }^{\dagger}$ and the Pittsburgh Liver Research Center, ${ }^{\ddagger}$ University of Pittsburgh, School of Medicine, Pittsburgh, Pennsylvania

Accepted for publication

September 22, 2021.

Address correspondence to Kari Nejak-Bowen, Ph.D., Department of Pathology, University of Pittsburgh, School of Medicine, 200 Lothrop Street, S405A Biomedical Science Tower, Pittsburgh, PA 15261. E-mail: knnst5@pitt. edu.

\begin{abstract}
Metabolic heterogeneity or functional zonation is a key characteristic of the liver that allows different metabolic pathways to be spatially regulated within the hepatic system and together contribute to whole body homeostasis. These metabolic pathways are segregated along the portocentral axis of the liver lobule into three hepatic zones: periportal, intermediate or midzonal, and perivenous. The liver performs complementary or opposing metabolic functions within different hepatic zones while synergistic functions are regulated by overlapping zones, thereby maintaining the overall physiological stability. The Wnt/ $\beta$ catenin signaling pathway is well known for its role in liver growth, development, and regeneration. In addition, the $W n t / \beta$-catenin pathway plays a fundamental and dominant role in hepatic zonation and signals to orchestrate various functions of liver metabolism and pathophysiology. The $\beta$-catenin protein is the central player in the Wnt/ $\beta$-catenin signaling cascade, and its activation is crucial for metabolic patterning of the liver. However, dysregulation of Wnt/ $\beta$-catenin signaling is also implicated in different liver pathologies, including those associated with metabolic syndrome. $\beta$-Catenin is preferentially localized in the central region of the hepatic lobule surrounding the central vein and regulates multiple functions of this region. This review outlines the role of Wnt/ $\beta$-catenin signaling pathway in controlling the different metabolic processes surrounding the central vein and its relation to liver homeostasis and dysfunction. (Am J Pathol 2022, 192: 4-17; https://doi.org/10.1016/j.ajpath.2021.09.007)
\end{abstract}

The liver is responsible for performing multiple physiological functions, including macronutrient metabolism, lipid and cholesterol homeostasis, endocrine and immune regulation, as well as breakdown of drugs to reduce toxicity. These multifunctional tasks are performed simultaneously by the liver because of its unique anatomic organization of hepatocytes, which are discretely arranged and yet synchronized to conduct all the necessary physiological processes. ${ }^{1}$ Such specialized hepatocytic organization within the liver is called liver or metabolic zonation, and it plays a critical role in the biochemical functionality of this organ. Any perturbation of the hepatic architecture causes pathologic alterations with permanent defects, leading to metabolic diseases.

The Wnt/ $\beta$-catenin signaling pathway is well known for its role in liver development, regeneration, and maintaining homeostatic balance. ${ }^{2}$ Activation of this pathway is critical for hepatic organogenesis, as evident by its involvement in hepatoblast proliferation, survival, and maturation. ${ }^{3}$ In addition, Wnt/ $\beta$-catenin signaling is a hallmark of various hepatic pathologies, including fibrosis, ${ }^{4}$ steatohepatitis, tumorigenesis, $^{6}$ and cholestasis. ${ }^{7}$ Such a diverse

Supported by National Institutes of Health grants R01DK103775 (K.N.B.), R01DK119435 (K.N.-B.), R01DK124412 (K.N.-B.) and P30DK120531 (Pittsburgh Liver Research Center).

The American Society for Investigative Pathology (ASIP) Cotran Early Career Investigator Award recognizes early career investigators with demonstrated excellence as an investigator with recently established or emerging independence and with a research focus leading to an improved understanding of the conceptual basis of disease. Kari Nejak-Bowen, recipient of the ASIP 2021 Cotran Early Career Investigator Award, delivered a lecture entitled "Therapeutic Implications of Modulating $\beta$-Catenin in Cholestasis" on April 30, 2021, at the virtual 2021 ASIP Annual Meeting at Experimental Biology.

Disclosures: S.P.M. is a consultant for Surrozen, Inc. 
complexity for the role of $\mathrm{Wnt} / \beta$-catenin pathway in regulating homeostatic functioning and/or pathophysiology of hepatic injury has been a subject of extensive research for the past several years, although much remains unknown. This review highlights one of the fundamental roles of Wnt/ $\beta$-catenin signaling in the liver, that of metabolic zonation, and the critical functions that are regulated by targets of this signaling pathway.

\section{Metabolic Zonation}

Under steady state, hepatocytes display molecular heterogeneity depending on their localization within hepatic lobule, the hexagon-shaped structure that is the smallest functional unit in the liver (Figure 1). ${ }^{1}$ Inside the hepatic lobule, hepatocytes are spatially segregated into three different zones: hepatocytes surrounding the portal triad (consisting of portal vein, bile ducts, and hepatic artery) constitute the periportal (afferent) zone 1; those surrounding the central vein form the perivenous or pericentral (efferent) zone 3 hepatocytes; and the intermediate hepatocytes sandwiched between the two zones are referred to as midzonal or intermediate perivenous zone $2 .{ }^{1}$ These differentially zonated hepatocytes line hepatic sinusoids along the portocentral axis, and although they share morphologic similarities, they exhibit functional metabolic heterogeneity, commonly known as metabolic or liver zonation. The term metabolic zonation means that the key steps involved in various metabolic functions are distributed spatially based on where a hepatocyte is located within the hepatic lobule. These zone-specific functions of hepatocytes are driven by oxygen and nutrient gradients, allowing for interdependent metabolic pathways to be colocalized in overlapping zones while performing complementary or opposing metabolic functions in spatially separated nonoverlapping zones. Consequently, the contribution of these hepatocytes in liver homeostasis involves a tight regulation of opposing metabolic processes with the periportal zone involved in gluconeogenesis, cholesterol biosynthesis, and oxidative phosphorylation, while the perivenous hepatocytes perform glycolysis, lipogenesis, bile acid biosynthesis, glutamine synthesis, and xenobiotic metabolism. ${ }^{8}$

For many years, it has been known that canonical Wnt signaling is a key regulator of metabolic zonation., ${ }^{9,10}$ $\mathrm{Wnt} / \beta$-catenin signaling is most active in the hepatocytes surrounding the central vein, owing to short-range Wnt ligands secreted by central-vein endothelial cells. $^{10-12}$ Consequently, during homeostasis, activated $\beta$-catenin is exclusively localized in the hepatocyte subpopulations surrounding the central vein. ${ }^{13,14}$ Gene expression in these so-called perivenous hepatocytes differs strikingly from the gene expression pattern observed in periportal hepatocytes. ${ }^{15}$ These differences have functional consequences on liver metabolism that will be discussed in detail below.

\section{Wnt/ $\beta$-Catenin Signaling and Activation of $\beta$-Catenin}

Canonical Wnt signaling is dependent on $\beta$-catenin, a transcriptional coactivator and effector of this pathway, to perpetuate the signal and regulate gene expression. Transduction through this pathway is initiated after binding of Wnt glycoproteins to the Frizzled receptor and the coreceptor low-density lipoprotein receptor-related protein (LRP) 5 or 6 on the plasma membrane. ${ }^{16}$ The Wnt-FrizzledLRP complex triggers the recruitment of the scaffolding protein Dishevelled (Dvl) and phosphorylation of LRP5/6. ${ }^{17}$ The latter further mediates recruitment of scaffold protein Axin to the plasma membrane. Axin forms a part of the destruction complex, comprising glycogen synthase kinase3 (GSK3), casein kinase $1 \alpha(\mathrm{CK} 1 \alpha)$, and tumor suppressor protein adenomatous polyposis coli (Apc), that together direct the phosphorylation and ubiquitination of $\beta$-catenin for its proteasomal degradation (Figure 2). ${ }^{18}$ The recruitment of Axin to the membrane disrupts the destruction complex, stabilizing $\beta$-catenin, which eventually translocates into the nucleus and binds with transcription factors T-cell factor/lymphocyte enhancer factor (TCF/LEF) to induce transcription of Wnt target genes.

\section{Role of $\beta$-Catenin in Hepatic Perivenous Zone Gene Expression}

The importance of $\mathrm{Wnt} / \beta$-catenin signaling in establishing liver metabolic zonation was first described in mice with liver-targeted inactivation of Apc. Deletion of this negative regulator of Wnt signaling activated $\beta$-catenin and switched the hepatocyte phenotype from periportal to perivenous. ${ }^{14}$ In the same study, it was also found that blocking hepatocyte $\beta$-catenin by overexpression of the Wnt antagonist Dickkopf-1 (Dkk1) down-regulated the expression of many perivenous genes and instead caused expansion of the periportal gene expression program. Subsequent studies confirmed the importance of $\beta$-catenin in maintaining homeostatic liver function through preservation of hepatic zonation. , $^{9,20}$

More recent work has also elucidated the cell and molecular circuitry upstream of $\beta$-catenin that governs zonation. $\beta$-Catenin is activated in zone 3 by Wnts originating from the adjacent endothelial cells of the central vein. ${ }^{11,21,22}$ In particular, Wnt2 and Wnt $9 \mathrm{~b}$ have been reported as major drivers of $\beta$-catenin activation in zone 3 (Figure 3). ${ }^{10,13}$ The R-spondin ligands and their leucine-rich repeat-containing G-protein coupled receptors (LGRs) $4 / 5$, which regulate the Wnt/ $\beta$-catenin gradient in liver, also help to control hepatic zonation. ${ }^{23,24}$ In addition, disruption of Wnt signaling by knockdown of liver-specific LRP5/6 leads to defective hepatic zonation and homeostasis despite intact $\beta$-catenin expression. ${ }^{21}$

Accordingly, perivenous hepatocytes express cytoplasmic and nuclear $\beta$-catenin along with membranous localization 
A

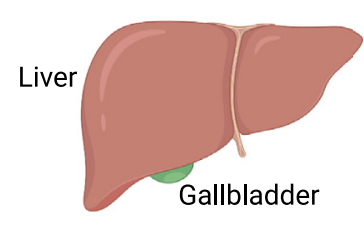

B

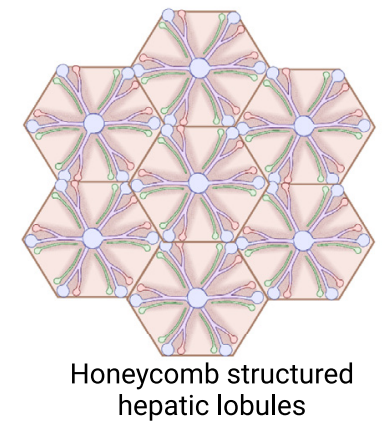

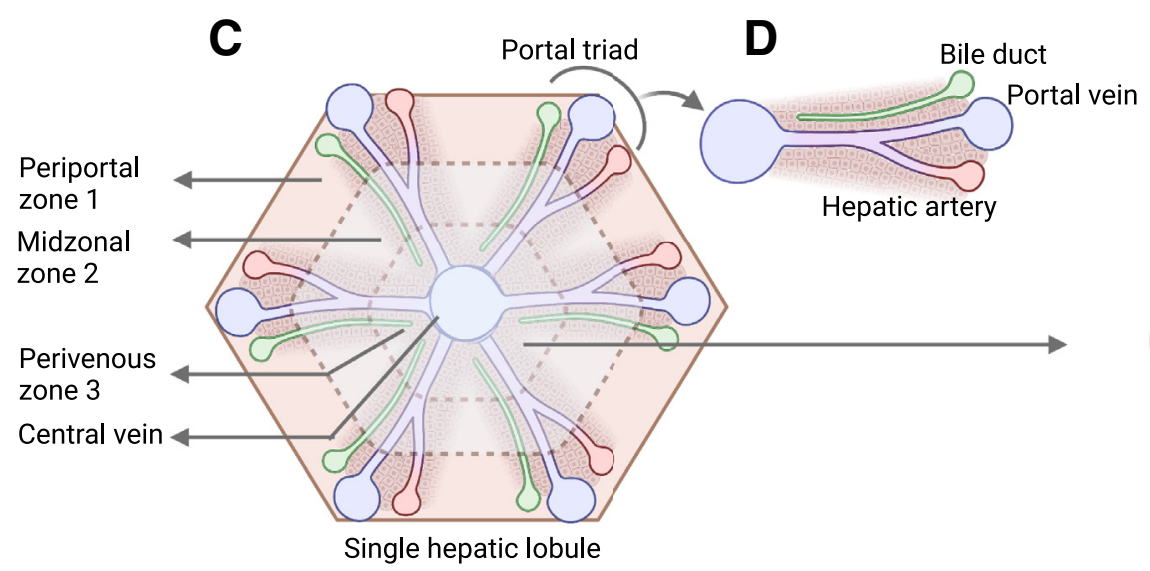

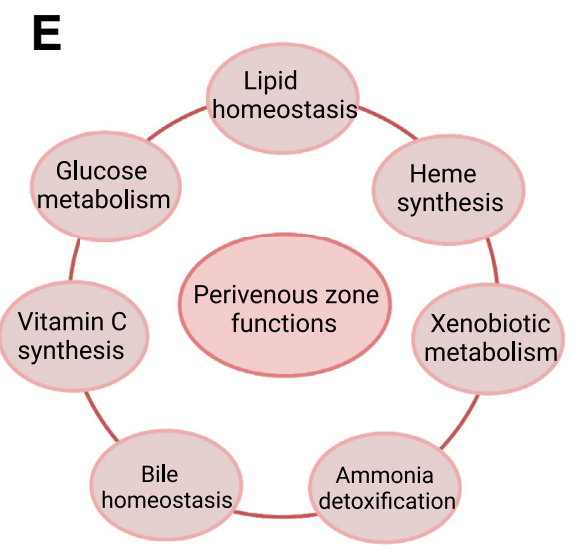

Figure 1 Metabolic liver zonation, showing the different hepatic zones within the basic structural hepatic lobule and the functional responsibilities of the centrilobular hepatocytes in the perivenous zone. A: Overview of liver. B: The basic structural units of liver, called the hepatic lobules, organized into a honeycomb-like architecture. C: A single hexagon-like hepatic lobule with central vein located at the center and multiple portal triads at the periphery. D: Enlarged view of a single portal triad composed of a hepatic artery, a portal vein, and a bile duct. E: Outline of different perivenous zonal responsibilities in the liver. Figure was prepared using Biorender.com (Toronto, ON, Canada).

of this transcriptional coactivator. Considering the preferential activation of $\beta$-catenin within the perivenous zone and its role in mediating the zone-specific gene expression pattern, it becomes imperative to understand and delineate the responsibilities of $\beta$-catenin in regulating the various metabolic processes that are confined to this zone (Table 1).

\section{Role of $\beta$-Catenin in Heme Biosynthesis}

Heme, an iron containing porphyrin, is an essential cofactor utilized in varied cellular processes, including oxygen binding, drug detoxification, and gene regulation at transcriptional and translational levels. ${ }^{25}$ Heme serves as the prosthetic group for hemoproteins, like the cytochrome P450 (CYP) family, as well as for hemoglobin, cytochrome $c$, catalases, and peroxidases. ${ }^{26}$ For a hemoprotein to be fully functional, it must be bound to its prosthetic group heme, the supply of which depends on the heme synthesis regulatory mechanisms.

Synthesis of heme is differentially regulated between erythrocytes in bone marrow and hepatocytes in the hepatic perivenous zone. ${ }^{25}$ Using murine models of hepatocytespecific deletion or overexpression of $\beta$-catenin, Braeuning and $\mathrm{Schwartz}^{26}$ reported four members of the heme synthesis pathway with preferential perivenous zonal localization [namely, aminolevulinate dehydratase (ALAD, alias porphobilinogen synthase), hydroxymethylbilane synthase (HMBS), coproporphyrinogen oxidase (CPOX), and uroporphyrinogen III synthase (UROS)]. The mRNA and protein expression of these enzymes was positively regulated by $\beta$-catenin activation. ${ }^{26}$ Hepatic zonation of these heme-synthesizing proteins was abolished in Ctnnbl or $\beta$ catenin knockout (KO) mice. Interestingly, no remarkable zonation for the first and rate-limiting enzyme of hemesynthesis pathway (i.e., aminolevulinate synthase 1 (ALAS 1) was observed.

A defect in any of the enzymes involved in heme biosynthesis can cause accumulation of pathway intermediates called protoporphyrins. These porphyrin precursors are cytotoxic, and their excessive accumulation over time leads to porphyriaassociated liver injury. ${ }^{27}$ Targeted deletion of Wnt//-catenin components or pharmacologic inhibition of this pathway decreased porphyrin accumulation in a murine model of porphyria that normally causes accumulation of porphyrin plugs associated with intermittent bile duct blockage. ${ }^{28}$ Decreased expression of heme biosynthesis enzymes aminolevulinate synthase 1 (ALAS) and aminolevulinate dehydratase (ALAD), the latter a direct target of $\mathrm{Wnt} / \beta$-catenin signaling, prevented accumulation of porphyrin intermediates, 

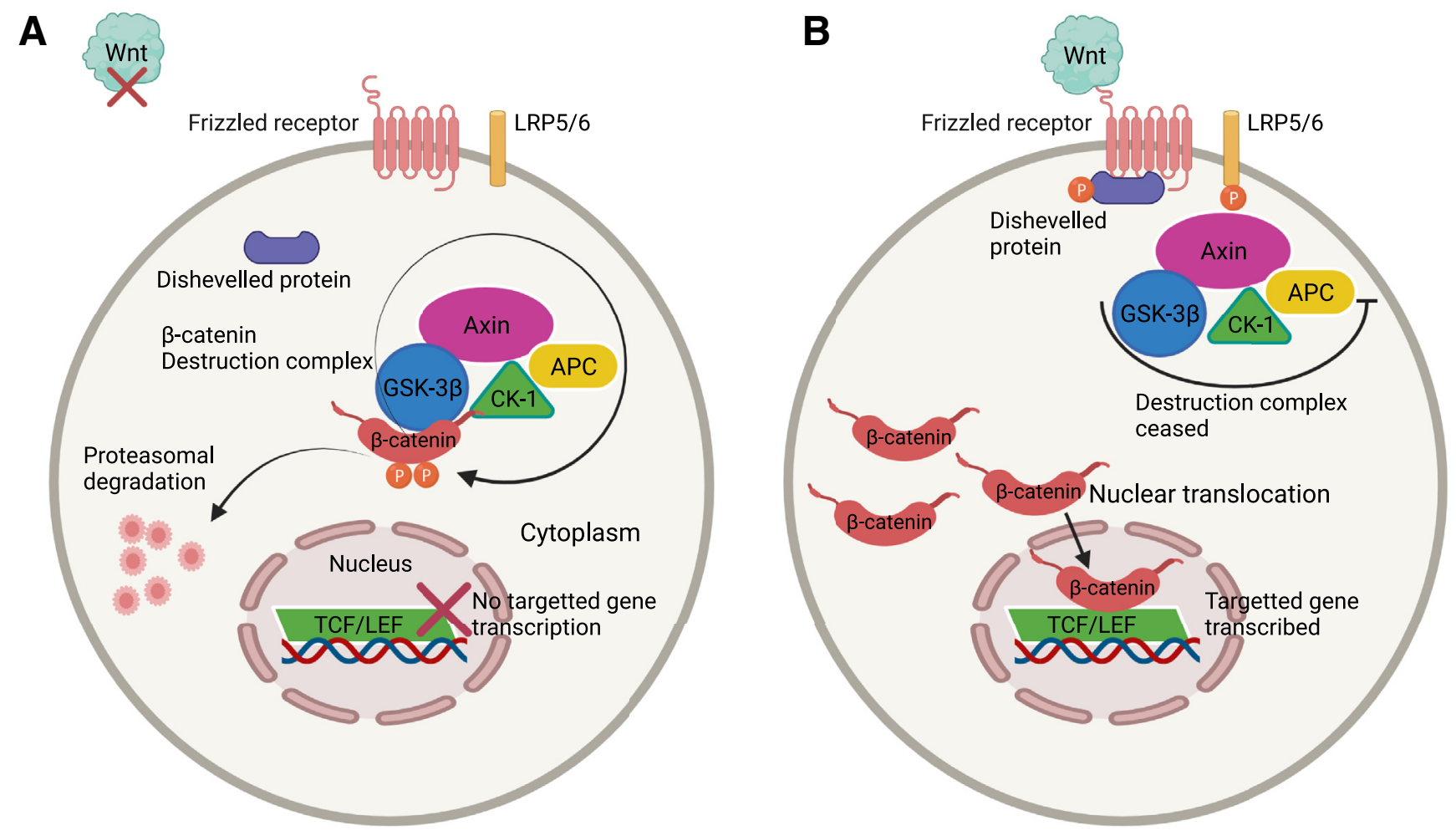

Figure 2 Wnt/ $\beta$-catenin signaling and $\beta$-catenin activation for target gene transcription. A: Wnt off situation: In the absence of Wnt glycoprotein, $\beta$-catenin, a transcriptional co-activator and the effector molecule of the pathway, is bound in a destruction complex consisting of Axin, adenomatous polyposis coli, casein kinase

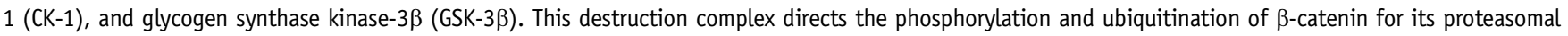
degradation with the net result that $\beta$-catenin-mediated gene transcription is not activated. B: Wnt on situation (canonical Wnt/ $\beta$-catenin signaling): When Wnt is present, it binds to the Frizzled receptor and coreceptor low-density lipoprotein receptor-related protein (LRP) 5/6. The Wnt-Frizzled-LRP complex causes dissociation of the destruction complex, which stabilizes $\beta$-catenin. The latter then translocates to the nucleus, where it binds to the transcription factors T-cell factor (TCF)/ lymphocyte enhancer factor (LEF), resulting in transcription of Wnt target genes. Figure was prepared using Biorender.com (Toronto, 0N, Canada).

leading to reduced protein aggregates and less liver injury. This study demonstrated the direct effect of Wnt/ $\beta$-catenin in regulating heme biosynthesis, and that this pathway can be targeted in heme-associated porphyria-mediated liver injury.

Heme oxygenase $(\mathrm{HO})$ is the rate-limiting enzyme in the catabolism of heme into biliverdin, iron, and carbon monoxide. The biliverdin formed is rapidly converted by biliverdin reductase to bilirubin. In cases of excessive bilirubin production, called hyperbilirubinemia, the risk of neurologic disorders increases, causing irreversible brain damage, such as kernicterus or bilirubin encephalopathy, which occurs in newborns with severe jaundice. ${ }^{29}$ Management of bilirubin levels by interfering with its formation is suggested as a better approach than employing inhibitors of heme oxygenase (HO) activity after bilirubin has reached toxic levels. ${ }^{30}$ Interestingly, liver-specific $\beta$-catenin $\mathrm{KO}$ mice had increased expression of $\mathrm{HO}$ concomitant with elevated serum bilirubin levels. ${ }^{31}$ Multidrug resistance protein 2 (Mdr2) KO mice lacking hepatocyte $\beta$-catenin had more severe cholestatic liver injury than Mdr2 $\mathrm{KO}$ alone; like $\beta$ catenin $\mathrm{KO}$, this mouse model also showed increased $\mathrm{HO}$ expression and bilirubin, which likely contributed to higher levels of oxidative stress and biliary injury. ${ }^{32}$ Therefore, activating $\beta$-catenin in patients with this condition might inhibit HO overexpression, which, in turn, could help reduce excessive heme catabolism and regulate hyperbilirubinemia and oxidative stress. Taken together, $\beta$-catenin is important in regulating the heme biosynthetic pathway as well as heme catabolism and consequently presents as a viable therapeutic target for diseases such as porphyria and hyperbilirubinemia.

\section{Regulation of Xenobiotic Metabolism and Cytochrome P450 Enzyme Expression by Wnt/ $\beta$-Catenin}

Liver is a central player in the metabolism and removal of potentially toxic compounds or xenobiotics, including drugs, pesticides, herbicides, food additives, or environmental chemicals, like carcinogens or mutagens. The cytochrome P450 monooxygenases are the major enzymes responsible for this process, and many of the isoforms, such as CYP2B1/2, CYP2E1, and CYP3A1, show a preferential perivenous hepatic zonal expression. ${ }^{33}$ CYPs are constitutively expressed or can be induced by ligand-activated nuclear receptors [namely, constitutive androstane receptor (CAR), pregnane $\mathrm{X}$ receptor (PXR), and aryl hydrocarbon 


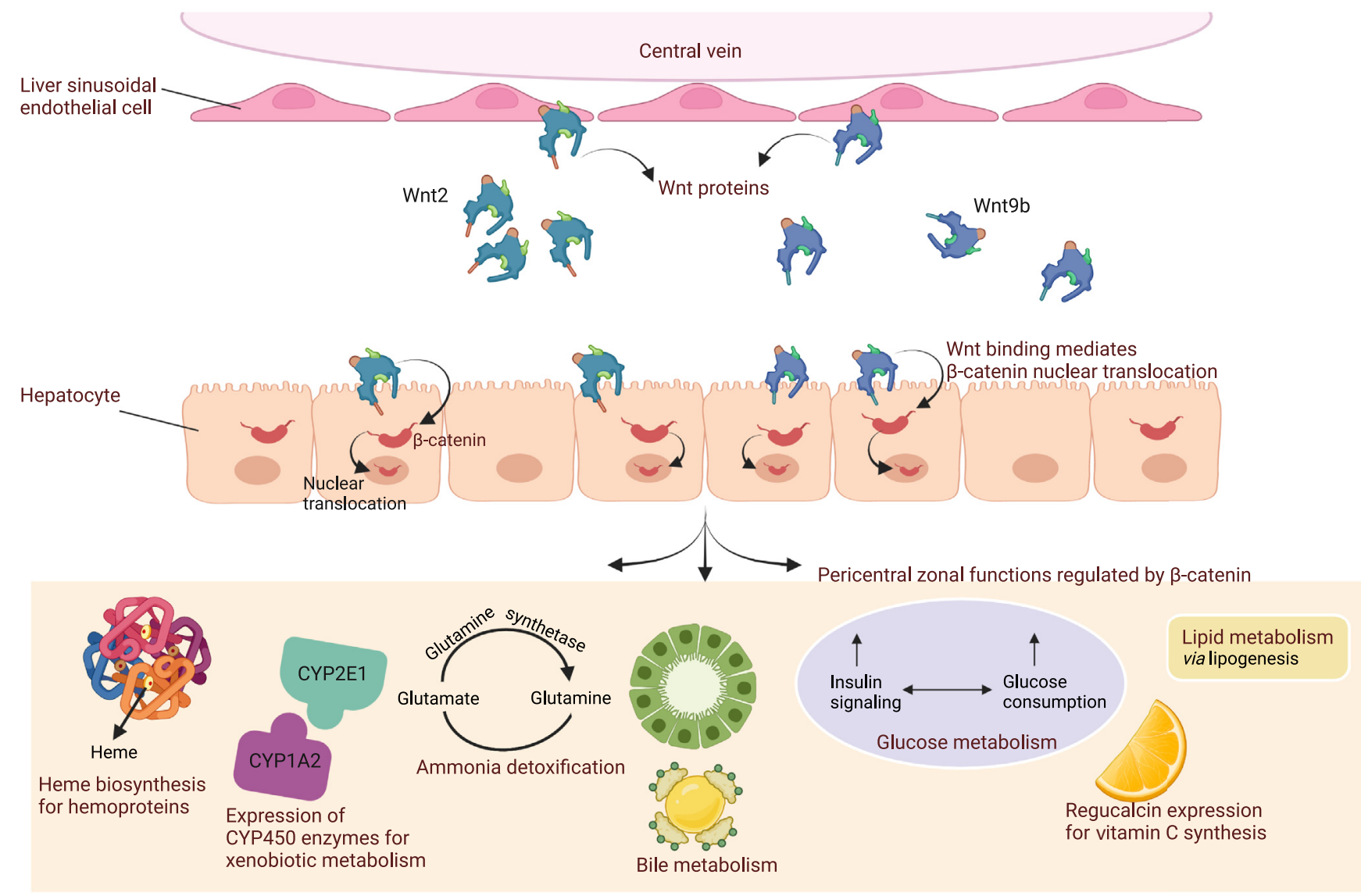

Figure 3 Schematic representation for the role of Wnt/ $\beta$-catenin signaling in regulating the different hepatic perivenous zonal functions and metabolic homeostasis. The Wnt proteins Wnt2 and Wnt9b, which are secreted by liver sinusoidal endothelial cells surrounding the central vein, bind to the hepatocyte cell membrane-associated receptor proteins. These Wnt proteins, via the canonical Wnt/ $\beta$-catenin signaling pathway, mediate $\beta$-catenin nuclear translocation and consequent activation of Wnt target genes. The net result is the regulation of several physiological and metabolic functions of the hepatic perivenous zone by $\beta$-catenin. Figure was prepared using Biorender.com (Toronto, ON, Canada). CYP, cytochrome P450.

receptor (AHR), ${ }^{34}$ or by the transcription factor peroxisome proliferator-activated receptor (PPAR)]. ${ }^{35}$ The expression and activity of most CYPs coincide with the zonal area where constitutive $\beta$-catenin activation is evident. Indeed, mouse livers tumors with activated $\beta$-catenin ${ }^{36}$ or transgenic mice expressing a mutant form of $\beta$-catenin ${ }^{37}$ have high levels of normally pericentrally localized CYP proteins. Likewise, hepatocyte-specific loss of $\beta$-catenin has been linked to loss of several CYP isoforms, including CYP2E1 and CYP1A2. ${ }^{19,38}$ These enzymes metabolize excessive acetaminophen (APAP) into the reactive metabolite $N$-acetyl- $p$-benzoquinone imine (NAPQI), which induces hepatic necrosis. Because both enzymes are target genes of $\beta$-catenin, liver-specific $\beta$-catenin $\mathrm{KO}$ mice are resistant to APAP-induced injury. ${ }^{19}$ The zonal expression of xenobiotic genes also allows a toxicant-induced injury to be limited to a specific zone, allowing hepatocytes residing in other zones to survive and restore liver mass through proliferation. For example, owing to the location of CYP2E1 and CYP1A2 to zone 3 hepatocytes, only these cells undergo necrosis following sublethal doses of APAP, allowing midzonal hepatocytes to proliferate and restore hepatic mass and architecture in a short time frame of 24 hours after insult. ${ }^{39}$ Intriguingly, as soon as zone 3 hepatocytes are destroyed by APAP overdose, midzonal hepatocytes begin to express other $\beta$-catenin zone 3 target genes, like glutamine synthetase (GS), ${ }^{40}$ to maintain vital functions, like that of scavenging excess ammonia for conversion to glutamine. This suggests that functional compensation of the liver occurs even before the recovery of hepatic mass and architecture. ${ }^{40}$

$\mathrm{Wnt} / \beta$-catenin signaling is an endogenous regulator of cytochrome $\mathrm{P} 450$ expression both at the basal level ${ }^{37}$ and in response to exposure to xenobiotic agonists of the nuclear receptors. ${ }^{41}$ Apart from CYP genes that constitute the phase I drug-metabolizing enzymes, $\beta$-catenin also modulates the activation and zonal expression of several members of the glutathione-S-transferase (GST) family that forms the phase II drug-metabolizing enzymes. ${ }^{42} \mathrm{~A}$ recent study demonstrated the requirement of $\beta$-catenin in $C Y P 2 C 8$ gene expression, and CAR-, and PXR-mediated induction of CYP1A, CYP2B6, and CYP3A4 genes in a human hepatocarcinoma cell line. ${ }^{43}$ On the contrary, activation of the 
Wnt/ $\beta$-catenin pathway inhibited PPAR $\alpha$-mediated induction of $C Y P 1 A, C Y P 2 C 8, C Y P 3 A 4$, and $C Y P 4 A 11$ genes, providing a dominant-negative role of $\beta$-catenin in regulation of these genes. So far, most of the reports on the role of $\beta$-catenin in zonal CYP regulation are from murine experimental models. However, considering mice metabolize many xenobiotics differently from humans due to species differences in $C Y P$ genes, it is possible that regulation of xenobiotic-metabolizing enzymes can differ between mice and humans. With the use of humanized-mouse model systems and metabolomics approaches, it has now become possible to overcome the potential species differences to more accurately predict the function and regulation of these enzymes in humans.

\section{Role of Wnt/ $\beta$-Catenin Signaling in Regulating Drug Transporters for Cancer Therapeutics}

In addition to the drug-metabolizing enzymes, membrane transporters play significant roles in drug disposition. The organic anion transporting polypeptide (OATP/SLCO) is one such family of uptake transporters that mediates sodiumindependent transport of a wide variety of structurally diverse endogenous compounds and xenobiotics. Of these, OATP1B1 (OATP2) and OATP1B3 (OATP8) are specifically found in the liver and expressed on the basolateral membrane of hepatocytes, wherein they participate in drug elimination. ${ }^{44}$ In normal livers, the expression of OATP1B1/B3 increases from portal (no expression) to perivenous areas (maximal expression) along sinusoids, ${ }^{45}$ resembling the expression pattern of $\beta$-catenin under physiological conditions.

Mutations in the CTNNB1 gene have been implicated in approximately one-quarter of hepatocellular carcinoma (HCC) cases. ${ }^{46}$ This particular subset of HCC has also been associated with activation of OATP1B3 expression in the perivenous region, suggesting a key role for $\beta$-catenin in regulating OATP1B3 expression. ${ }^{47}$ Analysis of mRNA expression further revealed significant correlation of OATP1B3 expression and Wnt/ $\beta$-catenin-associated genes, including CYP2E1, GS, OAT, AXIN2, and LGR5 ${ }^{48}$ In addition, GS expression and $\beta$-catenin nuclear expression strongly correlated with OATP1B3 expression score in immunohistochemical analyses. Case reports of $\beta$-catenin-activated hepatocellular adenoma also showed intense OATP1B3 expression, ${ }^{49}$ and equivalent-to-increased expression of OATP1B1/3 throughout the tumor. ${ }^{50}$ Thus, OATP1B3 up-regulation may be a candidate marker for $\mathrm{Wnt} / \beta$-catenin-activated hepatocellular lesions. Of the two subtypes of OATP1B3, (Lt)-OATP1B3 (hepatic type expressed in human liver) and (Ct) OATP1B3 (cancer type identified in cancer tissues and cell lines), the former mediates the uptake of many clinically important anticancer drugs, thereby expanding the potential clinical role of OATP1B3 in cancer treatment and drug disposition in the liver. ${ }^{51}$ Further studies will be needed to explore and correlate the expression levels of $(\mathrm{Ct})$ OATP1B3 in different types of $\beta$-catenin-mutated hepatocellular lesions.

\section{Wnt/ $\beta$-Catenin Regulation of Glutamine Synthetase for Ammonia Detoxification}

Ammonia is normally produced in the gastrointestinal tract as a by-product of amino acid metabolism or as a waste metabolite from gut bacteria and carried to the liver via portal vein where it is converted to urea for excretion by the kidneys. Within the liver, two systems participate in ammonia removal. First is the urea cycle, catalyzed by the enzyme carbamoyl phosphate synthetase I (CPSI) that is expressed in the hepatocytes of the periportal and intermediate zones, and a few adjacent layers of the perivenous zone. The second is a failsafe mechanism mediated by the enzyme GS that is exclusively localized to the first one to two layers of the hepatocytes closest to the central vein and catalyzes the ATP-dependent formation of glutamine from glutamate and ammonia. ${ }^{9}$ Any ammonia not taken up by urea system in the periportal zone is scavenged by GS in the perivenous hepatocytes.

The initial evidence for the role of $\beta$-catenin in ammonia detoxification came from the finding that active nuclear $\beta$-catenin signaling correlated with a significant increase in GS expression. ${ }^{52,53} \mathrm{Wnt} / \beta$-catenin-regulated zonation of GS is independent of c-Myc, a downstream effector of $\mathrm{Wnt} / \beta$ catenin signaling. ${ }^{54}$ Further studies showed that aberrant activation of $\beta$-catenin through loss of Apc results in expansion of the usually perivenous pattern of expression of GS toward the periportal area, as well as increased expression of other perivenous ammonia detoxification genes, such as ornithine aminotransferase $(O A T)$ and glutamate transporter 1 (GLTI). ${ }^{14}$ In parallel to this, loss of periportal expression of CPSI, the rate-limiting step of the urea cycle, was also observed. More important, loss of Apc leads to deficient ammonia detoxification and accumulation of glutamine due to loss of CPSI and subsequent dysfunction of the highcapacity urea cycle. On the contrary, blocking the Wnt/ $\beta$ catenin pathway by Wnt antagonist DKK1, a negative regulator of $\beta$-catenin signaling, resulted in decreased expression of glutamine metabolism genes, such as GS, OAT, and $G L T 1 .{ }^{14,53}$ Loss of $\beta$-catenin from hepatocytes also abolished GS expression from the perivenous zone. ${ }^{9,19}$ The functional significance of GS loss was highlighted by the observation that although $\beta$-catenin knockout mice demonstrated normal blood ammonia levels on a standard diet, there was a marked increase in blood ammonia levels in mice fed with a high-protein diet. ${ }^{19}$ Thus, ammonia metabolism in the liver is highly dependent on tight regulation of $\beta$-catenin expression; its absence in the periportal region permits activation of the urea cycle, whereas its presence in the perivenous zone activates GS to scavenge excess ammonia.

An important implication of GS being a direct target of $\mathrm{Wnt} / \beta$-catenin was recently shown in $\mathrm{HCC}$ with $\beta$-catenin 
Table 1 List of $\beta$-Catenin-Mediated Physiological Functions along with the Target Gene or Protein in the Perivenous Hepatic Zone

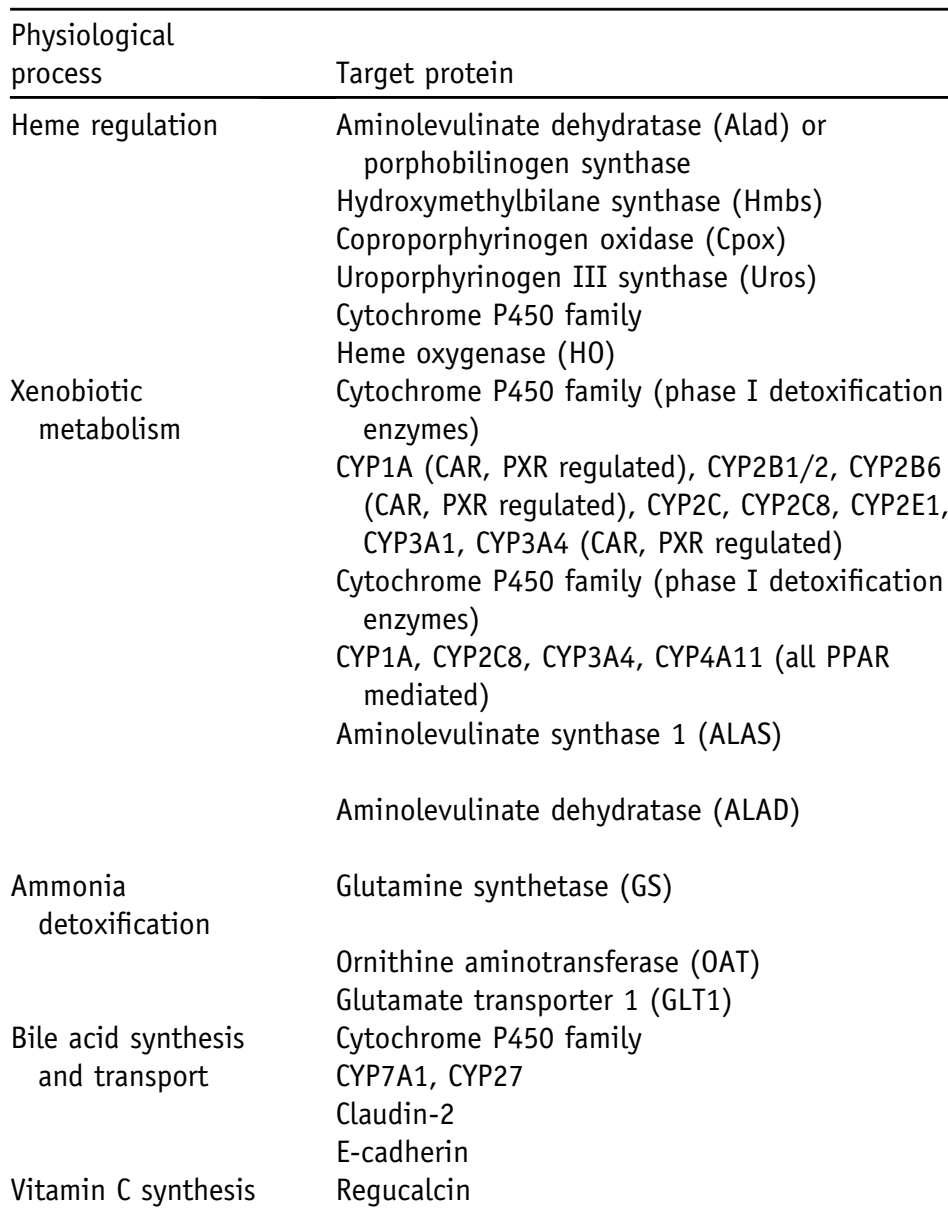

Glucose metabolism

Lipid metabolism and homeostasis

Glycolytic enzymes: glucokinase (GCK, PFK2) FBP2, phosphofructokinase 1 (PFK1, pyruvate kinase (PK)

Glucagon-like peptide-1

Kinases:

Akt

AMP-activated protein kinase (AMPK)

Pitx 2

Phosphoenolpyruvate carboxykinase

Insulin receptor substrate-1 (IRS1)

Cytochrome P450 enzyme:

CYP2E1

Function

Role of $\beta$-catenin

Heme biosynthesis

Positive regulation

Tight junction proteins

Alcohol dehydrogenase

Aldehyde dehydrogenase

hepatocyte nuclear factor $4 \alpha$ (HNF4 $\alpha$ )

GCK

mitochondrial glycerol-3-phosphate acyltransferase (mtGPAT) and diglyceride acyltransferase 2 (DGAT2)
Heme biosynthesis

Heme biosynthesis

Heme biosynthesis

Heme biosynthesis

Catabolism of heme

Drug detoxification

Drug detoxification

\section{Cytotoxic protoporphyrin IX formation \\ Cytotoxic protoporphyrin IX formation}

Ammonia to urea conversion

Ammonia to urea conversion

Ammonia metabolism

Synthesis of bile

Adherens junction protein

Encodes L-gulonolactone oxidase for vitamin C biosynthesis

Glucose uptake and utilization

Positive regulation Positive regulation Positive regulation Positive regulation Negative regulation Positive regulation

Negative regulation

Positive regulation

Positive regulation

Positive regulation

Positive regulation Positive regulation Positive regulation

Positive regulation Positive regulation Positive regulation

Positive regulation

Insulin secretion for glucose uptake

Phosphorylation of Fox0 proteins and decrease in gluconeogenesis

Proliferation of islet $\beta$-cells for insulin secretion

Decreases gluconeogenesis

Insulin signaling for glucose uptake

Alcohol metabolism

Positive regulation

Positive regulation

Positive regulation

Positive regulation Positive regulation

Positive regulation

Alcohol metabolism

Alcohol metabolism

Cholesterol and triglyceride metabolism

Encoding fatty acid synthase

Fatty acid esterification
Positive regulation Positive regulation Positive regulation

Positive regulation Positive regulation

(table continues) 
Table 1 (continued)

\begin{tabular}{lll}
\hline $\begin{array}{l}\text { Physiological } \\
\text { process }\end{array}$ & Target protein & Function \\
\hline $\begin{array}{l}\text { Drug disposition for } \\
\text { cancer therapy }\end{array}$ & OATP1B1 (OATP2) & Hepatic drug elimination \\
& OATP1B3 (OATP8) & Positive regulation \\
& & $\begin{array}{l}\text { Hepatic drug elimination, } \\
\text { uptake of anticancer drugs, } \\
\text { candidate marker of } \beta \text { - } \\
\text { catenin-activated } \\
\text { hepatocellular lesions }\end{array}$ \\
\hline
\end{tabular}

CAR, constitutive androstane receptor; FBP2, fructose-bisphosphatase 2; Fox = forkhead box; OATP, organic anion transporting polypeptide; Pitx = Pairedlike homeodomain 1; PPAR, peroxisome proliferator-activated receptor; PXR, pregnane $X$ receptor.

gene mutations. Owing to GS localization in most perivenous hepatocytes, and presumptively highest levels of intracellular glutamine in these cells, as well as the ability of glutamine to directly phosphorylate and activate the mechanistic target of rapamycin (mTOR) complex 1 in lysosomes, zone 3 hepatocytes in immediate proximity to the central vein were also positive for phosphorylated mTORserine2448. ${ }^{55}$ This marker of active mTOR complex 1 was negative in zone 3 hepatocytes in hepatocyte-specific knockouts of $\beta$-catenin, LRP5/6, and GS. $\beta$-Catenin-mutated HCCs, which are known to be strongly GS positive, were also positive for phosphorylated mTORserine 2448 and, hence, highly susceptible to mTOR inhibition in preclinical $\beta$-catenin-driven HCC models.

\section{Role of Wnt/ $\beta$-Catenin Signaling in Bile Acid Metabolism}

Recent evidence indicates that the Wnt/ $\beta$-catenin pathway also plays a role in regulating bile homeostasis, including bile synthesis, modification, and transport. Bile acids are synthesized from cholesterol via two pathways, which are initiated by either CYP7A1 or CYP27. ${ }^{56}$ Although cholesterol synthesis occurs predominantly in periportal hepatocytes, CYP7A1 and CYP27 are localized in the perivenous zone of the liver lobule, coincident with $\beta$-catenin activation. ${ }^{57}$ The close relationship between these two processes can be seen in $\beta$-catenin $\mathrm{KO}$ mice subjected to the methionine and cholinedeficient diet, which is characterized by macrovesicular steatosis and fibrosis. ${ }^{58}$ Liver-specific $\beta$-catenin deletion resulted in increased steatosis, higher hepatic cholesterol accumulation, and jaundice, likely due to defects in cholesterol to bile conversion mechanism and the bile export system. ${ }^{31}$ Intriguingly, $\beta$-catenin $\mathrm{KO}$ also had higher hepatic total bile acid levels on both methionine and choline-deficient and control diets, indicative of basal abnormalities in bile metabolism in the absence of $\beta$-catenin.

Disruption in bile canalicular transporter function or disruption of tight junction integrity in hepatocytes can also cause defective bile secretion and intrahepatic cholestasis. ${ }^{59,60}$ Loss of $\beta$-catenin from hepatocytes and cholangiocytes was associated with distorted bile canalicular morphology seen as dilatation, tortuosity, and loss of canalicular microvilli. ${ }^{7}$ These mice also had bile secretory defects and reduced bile flow, resulting in higher serum and hepatic total bile acid levels. ${ }^{7}$ Other studies have also reported that knockdown of claudin-2, a $\beta$-catenin target gene, prevents bile canalicular formation in vitro. ${ }^{61}$ Furthermore, depletion of $\beta$-catenin-E-cadherin-based adherens junctions causes defective canalicular lumen remodeling. ${ }^{62}$

Evidence that $\beta$-catenin has a direct effect on bile acid metabolism came from chromatin immunoprecipitation (ChIP)-sequencing studies, which showed CYP27 to be a transcriptional target of $\beta$-catenin. ${ }^{63}$ Subsequent studies suggested that CYP7A1 is also either a direct or an indirect target of Wnt signaling as CYP7A1 is suppressed basally in both $\beta$-catenin $\mathrm{KO}$ and LRP5/6 KO. ${ }^{64,65}$ Interestingly, $\beta$-catenin can also impact bile acid metabolism through its physical interaction with farnesoid $\mathrm{X}$ receptor(FXR), a nuclear receptor that regulates expression of bile acid efflux transporters and represses CYP7A1 expression through activation of small heterodimer partner(SHP). Lack of $\beta$-catenin eliminates FXR sequestration, leading to increased availability of FXR to decrease bile acid biosynthesis and stimulate its elimination, with the result that $\beta$-catenin $\mathrm{KO}$ have less liver injury, fibrosis, and atypical ductular proliferation after experimental cholestasis. ${ }^{64,65}$ Overexpression of oncogenic $\beta$-catenin in mice leads to cholestatic liver disease, whereas in humans, hepatocellular carcinoma with $\beta$-catenin gene mutations also exhibits intratumoral cholestasis. ${ }^{66,67}$ Because both CYP27 and CYP7A1 are expressed in the perivenous zone along with $\beta$-catenin, it is possible that excess $\beta$-catenin activates these two bile acid synthesis enzymes either directly or indirectly through inhibition of FXR around the central vein. These studies show that $\beta$-catenin plays a complex, multifaceted role in regulating bile acid metabolism that could have mechanistic and perhaps therapeutic implications for treatment of cholestatic liver disease.

\section{Canonical Wnt/ $\beta$-Catenin in Vitamin C Synthesis and Regulation}

Vitamin $\mathrm{C}$ or ascorbic acid is an essential dietary nutrient that has pleiotropic functions in the body, including as an 
enzyme cofactor, an antioxidant, and a component of both the innate and adaptive immune system. ${ }^{68}$ Paradoxically, humans and most animals, including zebrafish (but excluding mice), are unable to synthesize vitamin $\mathrm{C}$ because of a mutation in l-gulonolactone oxidase, the enzyme that catalyzes the last and rate-limiting step in the biosynthesis of this essential nutrient. ${ }^{69}$

The first indication that $\beta$-catenin may be playing a direct or indirect role in vitamin $\mathrm{C}$ biosynthesis in mice came from gene array analysis, which showed that regucalcin was one of the genes most affected by loss of $\beta$-catenin in liver. ${ }^{38}$ Regucalcin, also called senescence marker protein 30 , is a gluconolactonase that is important in cell homeostasis and function, and also catalyzes the penultimate step in the biosynthesis of vitamin $C .^{70}$ Livers of $\beta$-catenin knockout mice had deficiency in expression of both regucalcin and Lgulonolactone oxidase. ${ }^{71}$ These mice demonstrated low serum ascorbate levels associated with reduced basal hepatocyte survival. Additional analysis showed that regucalcin expression was more pronounced around the central veins, and molecular assays confirmed that regucalcin is a transcriptional target of $\beta$-catenin/TCF. ${ }^{71}$ Altogether, these observations support a role for $\beta$-catenin in regulating cell survival through vitamin $C$ biosynthesis.

Although $\beta$-catenin can regulate the vitamin $C$ pathway, it seems that the reciprocal is true as well. In a recent study, using vitamin $\mathrm{C}$-dietary model of zebrafish, Liu et $\mathrm{al}^{72}$ demonstrated the role of $\beta$-catenin signaling in mediating the lipid-lowering effect of vitamin C. In this model, vitamin $\mathrm{C}$-diet administration inhibited GSK-3 $\beta$ expression, which otherwise induces phosphorylation, ubiquitination, and degradation of $\beta$-catenin in the muscle of zebrafish. Inhibition of GSK-3 $\beta$ resulted in increased expression of $\beta$-catenin, ultimately leading to decreased fatty acid synthase activity and triglyceride levels. The overall result was lowering of lipid content and regulating lipid profile by vitamin $C$ through GSK-3 $\beta / \beta$-catenin signaling. ${ }^{72}$ Although the importance of $\beta$-catenin in regulating vitamin $C$ synthesis might be limited to preclinical models, the interplay between these two pathways, as well as $\beta$-catenin's role in cell survival, has implications that require further investigation.

\section{Role of Wnt/ $\beta$-Catenin Pathway in Glucose Metabolism and Associated Injury}

The presence of several enzyme-regulatory mechanisms in different hepatic zones enables the liver to perform the homeostatic function of glucose metabolism, regulating a tight switch between hepatic uptake or release of glucose to keep the blood sugar level within an optimal range. Such regulatory metabolic enzymes function in accordance to the concentration gradients of other metabolites, such as oxygen, hormones glucagon and insulin, and the morphogens Wnt and hedgehog, along the hepatic sinusoids.
Hepatocytes near the portal region are exposed to a high concentration of oxygen, which is required for anabolic processes that use ATP, such as gluconeogenesis. In contrast, hepatocytes close to the perivenous zone experience low levels of oxygen and thus are engaged in glucose uptake mechanisms, like glycolysis, an ATP-producing process that functions under conditions of oxygen deprivation. As a result, higher amounts of glycolytic enzymes glucokinase (GCK), phosphofructokinase 2/fructosebisphosphatase 2 (PFK2/FBP2), phosphofructokinase 1 (PFK1), and pyruvate kinase (PK) are found in the perivenous region, whereas the gluconeogenetic enzymes glucose-6-phosphatase (G6PC), fructose 1,6 bisphosphatase 1 (FBP1), mitochondrial pyruvate carboxylase (PCmito), and phosphoenolpyruvate carboxykinase 1 (PEPCK) are expressed in the periportal region. ${ }^{73}$ This is supported by earlier studies in rats that showed glucagon receptors involved in increasing blood glucose levels predominantly exist in the periportal region, whereas insulin receptors that participate in glucose consumption are abundantly expressed in the perivenous region. ${ }^{74}$ In addition, hepatic insulin receptor signaling is crucial for hepatic and systemic glucose homeostasis as lack of insulin receptor in the liver is associated with severe insulin resistance and hyperglycemia after feeding. ${ }^{75}$

Genome-wide association studies have linked the canonical Wnt/ $\beta$-catenin pathway to metabolic risk factors, with mutations in the components of this pathway associated with increased likelihood of developing metabolic syndrome and obesity phenotypes. ${ }^{76-79}$ A noncoding variant of transcription factor 7-like 2 (TCF7L2), commonly known as TCF4, the transcription factor that partners with $\beta$-catenin in the canonical Wnt signaling pathway, emerged as the strongest type 2 diabetes susceptibility gene that provided initial clues to the role of canonical Wnt signaling in glucose homeostasis. ${ }^{78}$ Further studies in mice showed that TCF7L2 is a downstream effector of insulin in hepatocytes and together with $\beta$-catenin negatively regulates hepatic gluconeogenesis. ${ }^{80} \mathrm{~A}$ single missense mutation in LRP6, the coreceptor for the Wnt signaling pathway, showed a strong genetic linkage with impaired glucose metabolism and hyperlipidemia. ${ }^{76}$ Mice lacking the Wnt coreceptor LRP5 also exhibited impaired pancreatic insulin secretion and thus impaired glucose uptake. ${ }^{81}$

Recent studies have further suggested that $\beta$-catenin plays a direct role in regulating serum glucose concentrations and modulating hepatic insulin signaling. Proteomics analysis showed that $\beta$-catenin positively regulates enzymes involved in glycolysis, such as lactate dehydrogenase, while negatively regulating the gluconeogenesis gene FBP1. ${ }^{82}$ Another study showed that $\beta$-catenin indirectly regulates glucokinase function through hypoxia-inducible factor 1 alpha (HIF1 $\alpha$ ), a transcriptional regulator of glycolysis that is subject to hypoxic regulation. ${ }^{83}$ Interestingly, however, there is some indication that $\beta$-catenin positively regulates gluconeogenesis as well, albeit not 
through canonical $\beta$-catenin/TCF activation. The forkhead family member FoxO1 regulates the expression of genes involved in de novo glucose synthesis, such as PEPCK and G6PC. ${ }^{84}$ Under conditions of oxidative stress, $\beta$-catenin can bind to FoxO family members, an interaction that inhibits $\beta$-catenin/TCF binding. ${ }^{85} \beta$-Catenin also preferentially binds to FoxO1 under fasting conditions, where it modulates the gluconeogenic response through regulation of PEPCK1 and G6PC. ${ }^{86}$ Thus, the switch in binding partners allows $\beta$-catenin to alter its functionality and target gene expression, depending on the nutritional requirements of the body. Another study showed that glucagon regulates metabolic zonation in the liver by opposing the Wnt/ $\beta$-catenin signaling pathway, enhancing periportal gene expression at the expense of the Wntdependent perivenous gene program. ${ }^{87}$ Thus, hepatic Wnt signaling functions in multiple capacities to regulate glucose homeostasis in liver.

Because of the association between hepatic pathologies, such as nonalcoholic fatty liver disease (NAFLD) and surplus calorie intake, studies in recent years have focused on the role of $\beta$-catenin in glucose metabolism under conditions of high-fat diet (HFD). Liver-specific conditional loss of $\beta$-catenin lowered fasting plasma glucose and improved glucose tolerance in HFD-fed mice, likely due to the decreased expression of hepatic gluconeogenic enzymes described above, together with improvements in insulin signaling in the absence of $\beta$-catenin. ${ }^{86}$ Another study by Behari et $\mathrm{al}^{83}$ reported improved hepatic insulin sensitivity and hepatic steatosis in liver-specific $\beta$-catenin knockout on HFD. Using second-generation antisense oligonucleotides to decrease hepatic and adipose $\beta$-catenin in mice exposed to HFD, a third group reported an improvement in hepatic insulin sensitivity and insulinstimulated whole body glucose metabolism associated with increased white adipose tissue and cardiac glucose uptake. $^{88}$ These findings were intriguing as they demonstrated the effect of reduced $\beta$-catenin in glucose homeostasis in contrast to other studies involving complete loss of liver $\beta$-catenin. As promising as these preclinical findings appear, a recent study in patients illustrates that glucose regulation is a complex process, and that $\beta$-catenin perturbation in this context may have multifactorial consequences. The insulin receptor substrate (IRS)-1, which is predominantly localized to the perivenous hepatic zone, is a direct transcriptional target of $\beta$-catenin. Decreased hepatic expression of IRS- 1 and $\beta$-catenin has been associated with histologic progression, such as ballooning in a prospective cohort study on NAFLD patients with a significant risk factor of developing type 2 diabetes due to impaired glucose metabolism. ${ }^{89}$ It seems that a coordinated regulatory mechanism involving a decrease in enzyme expression for gluconeogenesis simultaneous with an increase in insulin signaling plays a role in improving the final metabolic outcome observed in the HFD model systems and ultimately in patients as well.

\section{Regulation of Lipid Homeostasis by Wnt/ $\beta$ - Catenin Signaling}

The interconnected association between glucose, insulin, and lipid homeostasis is well known, and thus it is not surprising that in addition to glucose metabolism the Wnt signaling pathway is involved in regulating fatty acid metabolism as well. In the liver, the hepatic periportal zone, which has a higher oxygen gradient, conducts energyproducing fatty acid oxidation, whereas lipogenesis and triglyceride synthesis occur primarily in the perivenous region. ${ }^{90}$ As with glucose regulation, aberrations in $\mathrm{Wnt} / \beta$ catenin pathway components that affect lipid metabolism have been noted in patients. Mutations in the Wnt coreceptor LRP6 showed association with increased susceptibility toward hyperlipidemia in a family predisposed to metabolic syndrome. ${ }^{76}$ Mice expressing this mutated form of LRP6 have a similar phenotype and develop fatty liver disease due to increased lipogenesis and cholesterol synthesis, which is a function of enhanced mTOR/Akt signaling. Administrating Wnt3a partially reversed the hyperlipidemia induced by LRP6 deficiency and identified Wnt signaling as a regulator of plasma lipids. ${ }^{91}$ On the other hand, the same group showed that LRP6 heterozygous mice are protected from hepatic steatosis when fed a HFD due to decreased mTOR signaling and diminished expression of gluconeogenesis genes. ${ }^{92}$ The differential responses may be attributable to compensatory adaptation that is disrupted by a second hit, such as HFD, or by impaired ligand/receptor interactions in the mutated form of LRP6 compared with the half-maximal activation in the LRP6 heterozygous mice.

An important study implicating a direct role for $\beta$-catenin in lipid metabolism showed that mice transgenic for hepatocyte-specific stable $\beta$-catenin fed HFD had increased hepatic steatosis in perivenous and midzonal hepatocytes and threefold higher liver triglyceride levels compared with $\beta$-catenin KO or wild-type mice on HFD. ${ }^{83}$ These mice also developed diet-induced obesity and insulin resistance. In comparison to HFD-fed KO mice, the HFD-fed $\beta$-catenin transgenic mice also showed higher protein expression of the key metabolic enzymes hepatic fatty acid synthase and glucokinase, which are involved in lipogenesis and glycolysis, respectively, both of which are located in the perivenous zone. The increased hepatic lipogenesis in HFD-fed transgenic mice was independent of PPAR $\gamma$ expression, a major regulator of the lipogenic response. On the other hand, $\beta$-catenin $\mathrm{KO}$ mice were resistant to diet-induced obesity due to defective fatty acid oxidation, a result of lower perivenous hypoxia and decreased HIF1 $\alpha$ expression. These findings were supported by another study that targeted $\beta$-catenin mRNA expression level in the liver using antisense oligonucleotides (ASO), which resulted in reduced hepatic triglyceride levels as well as ameliorated hepatic steatosis and lipid-induced insulin resistance after HFD. ${ }^{88}$ This was caused by decreased expression of mitochondrial 
glycerol-3-phosphate acyltransferase (mtGPAT) and diglyceride acyltransferase 2 (DGAT2), the key enzymes of fatty acid esterification to generate triglycerides. Consequently, suppression of mtGPAT and DGAT2 prevented accumulation of triglycerides by decreasing lipogenesis and protected HFD-fed mice from hepatic steatosis. The results of these studies suggest that $\beta$-catenin has a profound effect on lipid metabolism under conditions of diet-induced fatty liver.

Other compounds, such as alcohol and hormones, can also impact the $\mathrm{Wnt} / \beta$-catenin-dependent regulation of lipid metabolism. Increased hepatic steatosis and liver triglycerides were observed in liver-specific $\beta$-catenin knockout mice fed liquid ethanol compared with wild-type controls. This was correlated with loss of $\beta$-catenin-regulated expression of enzymes, such as alcohol dehydrogenase, aldehyde dehydrogenase, and Cyp2E1, resulting in defective ethanol metabolism, systemic toxicity, and early mortality. ${ }^{93}$ In another recent study, Tian et $\mathrm{al}^{94}$ reported that a dominant negative form of $T C F 7 L 2$, identified above as being a type 2 diabetes risk gene, ${ }^{78}$ leads to elevated serum and hepatic lipid contents in male mice but not in females. The mechanism likely involves cross talk between $\beta$-catenin/TCF and the female hormone estradiol because reconstitution experiments with estradiol in wild-type females after ovariectomy attenuated HFD-induced lipid metabolic defects.

Hepatocyte nuclear factor 4 alpha (HNF4 $\alpha$ ), the master regulator of liver development and function, is a major contributing factor in lipid metabolism and homeostasis. Down-regulation of hepatic HNF4 $\alpha$ has been associated with hypolipidemia and nonalcoholic steatohepatitis. ${ }^{95-97}$ Interestingly, HNF $4 \alpha$ has a dual role in metabolic zonation by stimulating periportal but down-regulating perivenous genes, ${ }^{98}$ and may in fact cooperate with $\beta$-catenin to establish metabolic zonation in the liver. The Wnt downstream player lymphoid enhancer-binding factor 1 (LEF1) interacts with $\mathrm{HNF} 4 \alpha$ to dissociate it from its binding site, thus suppressing periportal gene expression in the perivenous region. ${ }^{99}$ In the perivenous region, $\beta$-catenin also binds directly to $\mathrm{HNF} 4 \alpha$, making it unavailable for activation of its target genes, whereas TCF binding to HNF4 $\alpha$ response elements further prevents their transcription. The reverse occurs in the periportal region; the presence of $\mathrm{HNF} 4 \alpha$ on $\beta$-catenin response elements prevents their transcription, while also binding to $\beta$-catenin and TCF to prevent their nuclear translocation. ${ }^{63}$ Moreover, $\mathrm{Wnt} / \beta$-catenin signaling is strongly activated in mice deficient for HNF4 $\alpha .{ }^{100}$ Loss of HNF4 $\alpha$ may alter the interaction of co-activators cAMP response element-binding protein-binding protein $(\mathrm{CBP})$ and $\mathrm{p} 300$ with $\beta$-catenin, resulting in marked deregulation of $\beta$-catenin signaling. However, the detailed signaling mechanisms by which the perivenous $\mathrm{Wnt} / \beta$ pathway interacts with HNF4 $\alpha$ for regulating lipid metabolism and homeostasis under different metabolic stress conditions are not clear.

\section{Conclusions and Future Perspectives}

The extensive research findings to date present sufficient evidence for the significant and indispensable role of canonical $W n t / \beta$-catenin signaling in regulating liver perivenous metabolic functions and homeostasis (Figure 3). However, the detailed molecular mechanisms of many of these $\beta$-catenin-mediated perivenous tasks need more investigation. A major weakness of the current findings is they are largely based on rodent and zebrafish models, and their relevance to human liver function would require further intensive evaluation. With the advancement of humanized-mouse model systems that exclude the risk of potential species differences, as well as advanced organoid culture systems and metabolomics approaches, future studies should focus on extrapolating the findings to human subjects for ultimate therapeutic management.

\section{References}

1. Gebhardt R, Matz-Soja M: Liver zonation: novel aspects of its regulation and its impact on homeostasis. World J Gastroenterol 2014, 20:8491-8504

2. Russell JO, Monga SP: Wnt/beta-catenin signaling in liver development, homeostasis, and pathobiology. Annu Rev Pathol 2018, 13: $351-378$

3. Tan X, Yuan Y, Zeng G, Apte U, Thompson MD, Cieply B, Stolz DB, Michalopoulos GK, Kaestner KH, Monga SP: Beta-catenin deletion in hepatoblasts disrupts hepatic morphogenesis and survival during mouse development. Hepatology 2008, 47:1667-1679

4. Cheng JH, She H, Han YP, Wang J, Xiong S, Asahina K, Tsukamoto H: Wnt antagonism inhibits hepatic stellate cell activation and liver fibrosis. Am J Physiol Gastrointest Liver Physiol 2008, 294: G39-G49

5. Lehwald N, Tao GZ, Jang KY, Papandreou I, Liu B, Liu B, Pysz MA Willmann JK, Knoefel WT, Denko NC, Sylvester KG: beta-Catenin regulates hepatic mitochondrial function and energy balance in mice. Gastroenterology 2012, 143:754-764

6. Monga SP: beta-Catenin signaling and roles in liver homeostasis, injury, and tumorigenesis. Gastroenterology 2015, 148:1294-1310

7. Yeh TH, Krauland L, Singh V, Zou B, Devaraj P, Stolz DB, Franks J, Monga SP, Sasatomi E, Behari J: Liver-specific beta-catenin knockout mice have bile canalicular abnormalities, bile secretory defect, and intrahepatic cholestasis. Hepatology 2010, 52:1410-1419

8. Jungermann K, Katz N: Functional hepatocellular heterogeneity. Hepatology 1982, 2:385-395

9. Burke ZD, Reed KR, Phesse TJ, Sansom OJ, Clarke AR, Tosh D Liver zonation occurs through a beta-catenin-dependent, c-Myc-independent mechanism. Gastroenterology 2009, 136:2316-2324.e3

10. Preziosi M, Okabe H, Poddar M, Singh S, Monga SP: Endothelial Wnts regulate beta-catenin signaling in murine liver zonation and regeneration: a sequel to the Wnt-Wnt situation. Hepatol Commun 2018, 2:845-860

11. Leibing T, Geraud C, Augustin I, Boutros M, Augustin HG Okun JG, Langhans CD, Zierow J, Wohlfeil SA, Olsavszky V, Schledzewski K, Goerdt S, Koch PS: Angiocrine Wnt signaling controls liver growth and metabolic maturation in mice. Hepatology 2018, 68:707-722

12. Halpern KB, Shenhav R, Massalha H, Toth B, Egozi A, Massasa EE, Medgalia C, David E, Giladi A, Moor AE, Porat Z, Amit I, Itzkovitz S: Paired-cell sequencing enables spatial gene expression mapping of liver endothelial cells. Nat Biotechnol 2018, 36:962-970 
13. Wang B, Zhao L, Fish M, Logan CY, Nusse R: Self-renewing diploid Axin2(+) cells fuel homeostatic renewal of the liver. Nature 2015, 524:180-185

14. Benhamouche S, Decaens T, Godard C, Chambrey R, Rickman DS, Moinard C, Vasseur-Cognet M, Kuo CJ, Kahn A, Perret C, Colnot S: Apc tumor suppressor gene is the "zonation-keeper" of mouse liver. Dev Cell 2006, 10:759-770

15. Braeuning A, Ittrich $\mathrm{C}$, Kohle $\mathrm{C}$, Hailfinger $\mathrm{S}$, Bonin $\mathrm{M}$, Buchmann A, Schwarz M: Differential gene expression in periportal and perivenous mouse hepatocytes. FEBS J 2006, 273:5051-5061

16. Wehrli M, Dougan ST, Caldwell K, O'Keefe L, Schwartz S, VaizelOhayon D, Schejter E, Tomlinson A, DiNardo S: Arrow encodes an LDL-receptor-related protein essential for wingless signalling. Nature 2000, 407:527-530

17. Habas R, Dawid IB: Dishevelled and Wnt signaling: is the nucleus the final frontier? J Biol 2005, 4:2

18. Tacchelly-Benites O, Wang Z, Yang E, Lee E, Ahmed Y: Toggling a conformational switch in Wnt/beta-catenin signaling: regulation of Axin phosphorylation: the phosphorylation state of Axin controls its scaffold function in two Wnt pathway protein complexes. Bioessays 2013, 35:1063-1070

19. Sekine S, Lan BY, Bedolli M, Feng S, Hebrok M: Liver-specific loss of beta-catenin blocks glutamine synthesis pathway activity and cytochrome p450 expression in mice. Hepatology 2006, 43:817-825

20. Torre C, Perret C, Colnot S: Transcription dynamics in a physiological process: beta-catenin signaling directs liver metabolic zonation. Int J Biochem Cell Biol 2011, 43:271-278

21. Yang J, Mowry LE, Nejak-Bowen KN, Okabe H, Diegel CR, Lang RA, Williams BO, Monga SP: beta-Catenin signaling in murine liver zonation and regeneration: a Wnt-Wnt situation! Hepatology 2014, 60:964-976

22. Ma R, Martinez-Ramirez AS, Borders TL, Gao F, Sosa-Pineda B: Metabolic and non-metabolic liver zonation is established nonsynchronously and requires sinusoidal Wnts. Elife 2020, 9:e46206

23. Rocha AS, Vidal V, Mertz M, Kendall TJ, Charlet A, Okamoto H, Schedl A: The angiocrine factor Rspondin3 is a key determinant of liver zonation. Cell Rep 2015, 13:1757-1764

24. Planas-Paz L, Orsini V, Boulter L, Calabrese D, Pikiolek M, Nigsch F, Xie Y, Roma G, Donovan A, Marti P, Beckmann N, Dill MT, Carbone W, Bergling S, Isken A, Mueller M, Kinzel B, Yang Y, Mao X, Nicholson TB, Zamponi R, Capodieci P, Valdez R, Rivera D, Loew A, Ukomadu C, Terracciano LM, Bouwmeester T, Cong F, Heim MH, Forbes SJ, Ruffner H, Tchorz JS: The RSPOLGR4/5-ZNRF3/RNF43 module controls liver zonation and size. Nat Cell Biol 2016, 18:467-479

25. Shetty T, Corson TW: Mitochondrial heme synthesis enzymes as therapeutic targets in vascular diseases. Front Pharmacol 2020, 11:1015

26. Braeuning A, Schwarz M: Zonation of heme synthesis enzymes in mouse liver and their regulation by beta-catenin and Ha-ras. Biol Chem 2010, 391:1305-1313

27. Smith AG, Foster JR: The association between chemical-induced porphyria and hepatic cancer. Toxicol Res (Camb) 2018, 7:647-663

28. Saggi H, Maitra D, Jiang A, Zhang R, Wang P, Cornuet P, Singh S, Locker J, Ma X, Dailey H, Abrams M, Omary MB, Monga SP, Nejak-Bowen K: Loss of hepatocyte beta-catenin protects mice from experimental porphyria-associated liver injury. J Hepatol 2019, 70: $108-117$

29. Cashore WJ, Oh W: Unbound bilirubin and kernicterus in low-birthweight infants. Pediatrics 1982, 69:481-485

30. Drummond GS, Baum J, Greenberg M, Lewis D, Abraham NG: HO1 overexpression and underexpression: clinical implications. Arch Biochem Biophys 2019, 673:108073

31. Behari J, Yeh TH, Krauland L, Otruba W, Cieply B, Hauth B, Apte U, Wu T, Evans R, Monga SP: Liver-specific beta-catenin knockout mice exhibit defective bile acid and cholesterol homeostasis and increased susceptibility to diet-induced steatohepatitis. Am J Pathol 2010, 176:744-753
32. Pradhan-Sundd T, Kosar K, Saggi H, Zhang R, Vats R, Cornuet P, Green S, Singh S, Zeng G, Sundd P, Nejak-Bowen K: Wnt/betacatenin signaling plays a protective role in the Mdr2 knockout murine model of cholestatic liver disease. Hepatology 2020, 71:1732-1749

33. Oinonen T, Lindros KO: Zonation of hepatic cytochrome P-450 expression and regulation. Biochem J 1998, 329:17-35

34. Kohle C, Bock KW: Coordinate regulation of human drug-metabolizing enzymes, and conjugate transporters by the Ah receptor, pregnane $\mathrm{X}$ receptor and constitutive androstane receptor. Biochem Pharmacol 2009, 77:689-699

35. Thomas M, Burk O, Klumpp B, Kandel BA, Damm G, Weiss TS, Klein K, Schwab M, Zanger UM: Direct transcriptional regulation of human hepatic cytochrome P450 3A4 (CYP3A4) by peroxisome proliferator-activated receptor alpha (PPARalpha). Mol Pharmacol 2013, 83:709-718

36. Loeppen S, Koehle C, Buchmann A, Schwarz M: A beta-catenindependent pathway regulates expression of cytochrome P450 isoforms in mouse liver tumors. Carcinogenesis 2005, 26:239-248

37. Braeuning A, Schwarz M: beta-Catenin as a multilayer modulator of zonal cytochrome P450 expression in mouse liver. Biol Chem 2010, 391:139-148

38. Tan X, Behari J, Cieply B, Michalopoulos GK, Monga SP: Conditional deletion of beta-catenin reveals its role in liver growth and regeneration. Gastroenterology 2006, 131:1561-1572

39. Bhushan B, Walesky C, Manley M, Gallagher T, Borude P, Edwards G, Monga SP, Apte U: Pro-regenerative signaling after acetaminophen-induced acute liver injury in mice identified using a novel incremental dose model. Am J Pathol 2014, 184:3013-3025

40. Walesky CM, Kolb KE, Winston CL, Henderson J, Kruft B, Fleming I, Ko S, Monga SP, Mueller F, Apte U, Shalek AK, Goessling W: Functional compensation precedes recovery of tissue mass following acute liver injury. Nat Commun 2020, 11:5785

41. Braeuning A, Sanna R, Huelsken J, Schwarz M: Inducibility of drugmetabolizing enzymes by xenobiotics in mice with liver-specific knockout of Ctnnb1. Drug Metab Dispos 2009, 37:1138-1145

42. Giera S, Braeuning A, Kohle C, Bursch W, Metzger U, Buchmann A, Schwarz M: Wnt/beta-catenin signaling activates and determines hepatic zonal expression of glutathione S-transferases in mouse liver. Toxicol Sci 2010, 115:22-33

43. Thomas M, Bayha C, Vetter S, Hofmann U, Schwarz M, Zanger UM, Braeuning A: Activating and inhibitory functions of WNT/betacatenin in the induction of cytochromes $\mathrm{P} 450$ by nuclear receptors in HepaRG cells. Mol Pharmacol 2015, 87:1013-1020

44. Smith NF, Figg WD, Sparreboom A: Role of the liver-specific transporters OATP1B1 and OATP1B3 in governing drug elimination. Expert Opin Drug Metab Toxicol 2005, 1:429-445

45. Obaidat A, Roth M, Hagenbuch B: The expression and function of organic anion transporting polypeptides in normal tissues and in cancer. Annu Rev Pharmacol Toxicol 2012, 52:135-151

46. de La Coste A, Romagnolo B, Billuart P, Renard CA, Buendia MA, Soubrane O, Fabre M, Chelly J, Beldjord C, Kahn A, Perret C: Somatic mutations of the beta-catenin gene are frequent in mouse and human hepatocellular carcinomas. Proc Natl Acad Sci U S A 1998, 95:8847-8851

47. Sekine S, Ogawa R, Ojima H, Kanai Y: Expression of SLCO1B3 is associated with intratumoral cholestasis and CTNNB1 mutations in hepatocellular carcinoma. Cancer Sci 2011, 102:1742-1747

48. Ueno A, Masugi Y, Yamazaki K, Komuta M, Effendi K, Tanami Y, Tsujikawa H, Tanimoto A, Okuda S, Itano O, Kitagawa Y, Kuribayashi S, Sakamoto M: OATP1B3 expression is strongly associated with Wnt/beta-catenin signalling and represents the transporter of gadoxetic acid in hepatocellular carcinoma. J Hepatol 2014, 61: 1080-1087

49. Yoneda N, Matsui O, Kitao A, Kozaka K, Gabata T, Sasaki M, Nakanuma Y, Murata K, Tani T: Beta-catenin-activated hepatocellular adenoma showing hyperintensity on hepatobiliary-phase gadoxetic-enhanced magnetic resonance imaging and overexpression of OATP8. Jpn J Radiol 2012, 30:777-782 
50. Ba-Ssalamah A, Antunes C, Feier D, Bastati N, Hodge JC, Stift J, Cipriano MA, Wrba F, Trauner M, Herold CJ, Caseiro-Alves F: Morphologic and molecular features of hepatocellular adenoma with gadoxetic acid-enhanced MR imaging. Radiology 2015, 277:104-113

51. Li TT, An JX, Xu JY, Tuo BG: Overview of organic anion transporters and organic anion transporter polypeptides and their roles in the liver. World J Clin Cases 2019, 7:3915-3933

52. Loeppen S, Schneider D, Gaunitz F, Gebhardt R, Kurek R, Buchmann A, Schwarz M: Overexpression of glutamine synthetase is associated with beta-catenin-mutations in mouse liver tumors during promotion of hepatocarcinogenesis by phenobarbital. Cancer Res 2002, 62:5685-5688

53. Cadoret A, Ovejero C, Terris B, Souil E, Levy L, Lamers WH, Kitajewski J, Kahn A, Perret C: New targets of beta-catenin signaling in the liver are involved in the glutamine metabolism. Oncogene 2002, 21:8293-8301

54. Reed KR, Athineos D, Meniel VS, Wilkins JA, Ridgway RA, Burke ZD, Muncan V, Clarke AR, Sansom OJ: B-catenin deficiency, but not Myc deletion, suppresses the immediate phenotypes of APC loss in the liver. Proc Natl Acad Sci U S A 2008, 105:18919-18923

55. Adebayo Michael AO, Ko S, Tao J, Moghe A, Yang H, Xu M, Russell JO, Pradhan-Sundd T, Liu S, Singh S, Poddar M, Monga JS, Liu P, Oertel M, Ranganathan S, Singhi A, Rebouissou S, ZucmanRossi J, Ribback S, Calvisi D, Qvartskhava N, Gorg B, Haussinger D, Chen X, Monga SP: Inhibiting glutamine-dependent mTORC1 activation ameliorates liver cancers driven by beta-catenin mutations. Cell Metab 2019, 29:1135-1150.e6

56. Javitt NB: Bile acid synthesis from cholesterol: regulatory and auxiliary pathways. FASEB J 1994, 8:1308-1311

57. Twisk J, Hoekman MF, Mager WH, Moorman AF, de Boer PA, Scheja L, Princen HM, Gebhardt R: Heterogeneous expression of cholesterol 7 alpha-hydroxylase and sterol 27-hydroxylase genes in the rat liver lobulus. J Clin Invest 1995, 95:1235-1243

58. Leclercq IA, Farrell GC, Field J, Bell DR, Gonzalez FJ, Robertson GR: CYP2E1 and CYP4A as microsomal catalysts of lipid peroxides in murine nonalcoholic steatohepatitis. J Clin Invest 2000, 105:1067-1075

59. Wagner M, Zollner G, Trauner M: New molecular insights into the mechanisms of cholestasis. J Hepatol 2009, 51:565-580

60. Kojima T, Yamamoto T, Murata M, Chiba H, Kokai Y, Sawada N: Regulation of the blood-biliary barrier: interaction between gap and tight junctions in hepatocytes. Med Electron Microsc 2003, 36: $157-164$

61. Son S, Kojima T, Decaens C, Yamaguchi H, Ito T, Imamura M, Murata M, Tanaka S, Chiba H, Hirata K, Sawada N: Knockdown of tight junction protein claudin-2 prevents bile canalicular formation in WIF-B9 cells. Histochem Cell Biol 2009, 131:411-424

62. Theard D, Steiner M, Kalicharan D, Hoekstra D, van Ijzendoorn SC: Cell polarity development and protein trafficking in hepatocytes lacking E-cadherin/beta-catenin-based adherens junctions. Mol Biol Cell 2007, 18:2313-2321

63. Gougelet A, Torre C, Veber P, Sartor C, Bachelot L, Denechaud PD, Godard C, Moldes M, Burnol AF, Dubuquoy C, Terris B, Guillonneau F, Ye T, Schwarz M, Braeuning A, Perret C, Colnot S: T-cell factor 4 and beta-catenin chromatin occupancies pattern zonal liver metabolism in mice. Hepatology 2014, 59:2344-2357

64. Thompson MD, Moghe A, Cornuet P, Marino R, Tian J, Wang P, Ma X, Abrams M, Locker J, Monga SP, Nejak-Bowen K: beta-Catenin regulation of farnesoid $\mathrm{X}$ receptor signaling and bile acid metabolism during murine cholestasis. Hepatology 2018, 67:955-971

65. Zhang R, Nakao T, Luo J, Xue Y, Cornuet P, Oertel M, Kosar K, Singh S, Nejak-Bowen K: Activation of WNT/beta-catenin signaling and regulation of the farnesoid $\mathrm{X}$ receptor/beta-catenin complex after murine bile duct ligation. Hepatol Commun 2019, 3:1642-1655

66. Lemberger UJ, Fuchs CD, Karer M, Haas S, Stojakovic T, Schofer C, Marschall HU, Wrba F, Taketo MM, Egger G, Trauner M, Osterreicher $\mathrm{CH}$ : Hepatocyte specific expression of an oncogenic variant of beta-catenin results in cholestatic liver disease. Oncotarget 2016, 7:86985-86998

67. Audard V, Grimber G, Elie C, Radenen B, Audebourg A, Letourneur F, Soubrane O, Vacher-Lavenu MC, Perret C, Cavard C, Terris B: Cholestasis is a marker for hepatocellular carcinomas displaying beta-catenin mutations. J Pathol 2007, 212:345-352

68. Carr AC, Maggini S: Vitamin C and immune function. Nutrients 2017, 9:1211

69. Linster CL, Van Schaftingen E: Vitamin C: biosynthesis, recycling and degradation in mammals. FEBS J 2007, 274:1-22

70. Yamaguchi M: Role of regucalcin in maintaining cell homeostasis and function (review). Int J Mol Med 2005, 15:371-389

71. Nejak-Bowen KN, Zeng G, Tan X, Cieply B, Monga SP: Beta-catenin regulates vitamin $\mathrm{C}$ biosynthesis and cell survival in murine liver. J Biol Chem 2009, 284:28115-28127

72. Liu D, Yu H, Pang Q, Zhang X: Investigation of the lipid-lowering effect of vitamin $\mathrm{C}$ through GSK-3beta/beta-catenin signaling in zebrafish. Front Physiol 2018, 9:1023

73. Berndt N, Horger MS, Bulik S, Holzhutter HG: A multiscale modelling approach to assess the impact of metabolic zonation and microperfusion on the hepatic carbohydrate metabolism. PLoS Comput Biol 2018, 14:e1006005

74. Krones A, Kietzmann T, Jungermann K: Perivenous localization of insulin receptor protein in rat liver, and regulation of its expression by glucose and oxygen in hepatocyte cultures. Biochem J 2000, 348 Pt 2: 433-438

75. Michael MD, Kulkarni RN, Postic C, Previs SF, Shulman GI, Magnuson MA, Kahn CR: Loss of insulin signaling in hepatocytes leads to severe insulin resistance and progressive hepatic dysfunction. Mol Cell 2000, 6:87-97

76. Mani A, Radhakrishnan J, Wang H, Mani A, Mani MA, NelsonWilliams C, Carew KS, Mane S, Najmabadi H, Wu D, Lifton RP: LRP6 mutation in a family with early coronary disease and metabolic risk factors. Science 2007, 315:1278-1282

77. Christodoulides C, Scarda A, Granzotto M, Milan G, Dalla Nora E, Keogh J, De Pergola G, Stirling H, Pannacciulli N, Sethi JK, Federspil G, Vidal-Puig A, Farooqi IS, O'Rahilly S, Vettor R: WNT10B mutations in human obesity. Diabetologia 2006, 49:678-684

78. Grant SF, Thorleifsson G, Reynisdottir I, Benediktsson R, Manolescu A, Sainz J, Helgason A, Stefansson H, Emilsson V, Helgadottir A, Styrkarsdottir U, Magnusson KP, Walters GB, Palsdottir E, Jonsdottir T, Gudmundsdottir T, Gylfason A, Saemundsdottir J, Wilensky RL, Reilly MP, Rader DJ, Bagger Y, Christiansen C, Gudnason V, Sigurdsson G, Thorsteinsdottir U, Gulcher JR, Kong A, Stefansson K: Variant of transcription factor 7 like 2 (TCF7L2) gene confers risk of type 2 diabetes. Nat Genet 2006 , $38: 320-323$

79. Guo YF, Xiong DH, Shen H, Zhao LJ, Xiao P, Guo Y, Wang W, Yang TL, Recker RR, Deng HW: Polymorphisms of the low-density lipoprotein receptor-related protein 5 (LRP5) gene are associated with obesity phenotypes in a large family-based association study. J Med Genet 2006, 43:798-803

80. Ip W, Shao W, Chiang YT, Jin T: The Wnt signaling pathway effector TCF7L2 is upregulated by insulin and represses hepatic gluconeogenesis. Am J Physiol Endocrinol Metab 2012, 303: E1166-E1176

81. Fujino T, Asaba H, Kang MJ, Ikeda Y, Sone H, Takada S, Kim DH, Ioka RX, Ono M, Tomoyori H, Okubo M, Murase T, Kamataki A, Yamamoto J, Magoori K, Takahashi S, Miyamoto Y, Oishi H, Nose M, Okazaki M, Usui S, Imaizumi K, Yanagisawa M, Sakai J, Yamamoto TT: Low-density lipoprotein receptor-related protein 5 (LRP5) is essential for normal cholesterol metabolism and glucoseinduced insulin secretion. Proc Natl Acad Sci U S A 2003, 100: 229-234

82. Chafey P, Finzi L, Boisgard R, Cauzac M, Clary G, Broussard C, Pegorier JP, Guillonneau F, Mayeux P, Camoin L, Tavitian B, Colnot S, Perret C: Proteomic analysis of beta-catenin activation in 
mouse liver by DIGE analysis identifies glucose metabolism as a new target of the Wnt pathway. Proteomics 2009, 9:3889-3900

83. Behari J, Li H, Liu S, Stefanovic-Racic M, Alonso L, O’Donnell CP, Shiva S, Singamsetty S, Watanabe Y, Singh VP, Liu Q: beta-Catenin links hepatic metabolic zonation with lipid metabolism and dietinduced obesity in mice. Am J Pathol 2014, 184:3284-3298

84. Puigserver P, Rhee J, Donovan J, Walkey CJ, Yoon JC, Oriente F, Kitamura Y, Altomonte J, Dong H, Accili D, Spiegelman BM: Insulin-regulated hepatic gluconeogenesis through FOXO1-PGC1alpha interaction. Nature 2003, 423:550-555

85. Hoogeboom D, Essers MA, Polderman PE, Voets E, Smits LM, Burgering BM: Interaction of FOXO with beta-catenin inhibits betacatenin/T cell factor activity. J Biol Chem 2008, 283:9224-9230

86. Liu H, Fergusson MM, Wu JJ, Rovira II, Liu J, Gavrilova O, Lu T, Bao J, Han D, Sack MN, Finkel T: Wnt signaling regulates hepatic metabolism. Sci Signal 2011, 4:ra6

87. Cheng X, Kim SY, Okamoto H, Xin Y, Yancopoulos GD, Murphy AJ, Gromada J: Glucagon contributes to liver zonation. Proc Natl Acad Sci U S A 2018, 115:E4111-E4119

88. Popov VB, Jornayvaz FR, Akgul EO, Kanda S, Jurczak MJ, Zhang D, Abudukadier A, Majumdar SK, Guigni B, Petersen KF, Manchem VP, Bhanot S, Shulman GI, Samuel VT: Second-generation antisense oligonucleotides against beta-catenin protect mice against diet-induced hepatic steatosis and hepatic and peripheral insulin resistance. FASEB J 2016, 30:1207-1217

89. Enooku K, Kondo M, Fujiwara N, Sasako T, Shibahara J, Kado A, Okushin K, Fujinaga H, Tsutsumi T, Nakagomi R, Minami T, Sato M, Nakagawa H, Kondo Y, Asaoka Y, Tateishi R, Ueki K, Ikeda H, Yoshida H, Moriya K, Yotsuyanagi H, Kadowaki T, Fukayama M, Koike K: Hepatic IRS1 and ss-catenin expression is associated with histological progression and overt diabetes emergence in NAFLD patients. J Gastroenterol 2018, 53:1261-1275

90. Schleicher J, Tokarski C, Marbach E, Matz-Soja M, Zellmer S, Gebhardt R, Schuster S: Zonation of hepatic fatty acid metabolism the diversity of its regulation and the benefit of modeling. Biochim Biophys Acta 2015, 1851:641-656

91. Go GW, Srivastava R, Hernandez-Ono A, Gang G, Smith SB, Booth CJ, Ginsberg HN, Mani A: The combined hyperlipidemia caused by impaired Wnt-LRP6 signaling is reversed by Wnt3a rescue. Cell Metab 2014, 19:209-220
92. Liu W, Singh R, Choi CS, Lee HY, Keramati AR, Samuel VT, Lifton RP, Shulman GI, Mani A: Low density lipoprotein (LDL) receptor-related protein 6 (LRP6) regulates body fat and glucose homeostasis by modulating nutrient sensing pathways and mitochondrial energy expenditure. J Biol Chem 2012, 287: $7213-7223$

93. Liu S, Yeh TH, Singh VP, Shiva S, Krauland L, Li H, Zhang P, Kharbanda K, Ritov V, Monga SP, Scott DK, Eagon PK, Behari J: beta-Catenin is essential for ethanol metabolism and protection against alcohol-mediated liver steatosis in mice. Hepatology 2012, 55:931-940

94. Tian L, Shao W, Ip W, Song Z, Badakhshi Y, Jin T: The developmental Wnt signaling pathway effector beta-catenin/TCF mediates hepatic functions of the sex hormone estradiol in regulating lipid metabolism. PLoS Biol 2019, 17:e3000444

95. Xu Y, Zalzala M, Xu J, Li Y, Yin L, Zhang Y: A metabolic stressinducible miR-34a-HNF4alpha pathway regulates lipid and lipoprotein metabolism. Nat Commun 2015, 6:7466

96. Hayhurst GP, Lee YH, Lambert G, Ward JM, Gonzalez FJ: Hepatocyte nuclear factor 4alpha (nuclear receptor 2A1) is essential for maintenance of hepatic gene expression and lipid homeostasis. Mol Cell Biol 2001, 21:1393-1403

97. Yin L, Ma H, Ge X, Edwards PA, Zhang Y: Hepatic hepatocyte nuclear factor 4alpha is essential for maintaining triglyceride and cholesterol homeostasis. Arterioscler Thromb Vasc Biol 2011, 31: 328-336

98. Stanulovic VS, Kyrmizi I, Kruithof-de Julio M, Hoogenkamp M, Vermeulen JL, Ruijter JM, Talianidis I, Hakvoort TB, Lamers WH: Hepatic HNF4alpha deficiency induces periportal expression of glutamine synthetase and other pericentral enzymes. Hepatology 2007, 45:433-444

99. Colletti M, Cicchini C, Conigliaro A, Santangelo L, Alonzi T, Pasquini E, Tripodi M, Amicone L: Convergence of Wnt signaling on the HNF4alpha-driven transcription in controlling liver zonation. Gastroenterology 2009, 137:660-672

100. Walesky C, Gunewardena S, Terwilliger EF, Edwards G, Borude P, Apte U: Hepatocyte-specific deletion of hepatocyte nuclear factor-4alpha in adult mice results in increased hepatocyte proliferation. Am J Physiol Gastrointest Liver Physiol 2013, 304: G26-G37 